\title{
The Church and Slavery in Anglo-Saxon England
}

\section{Pat Dutchak}

Slaves and slavery were an accepted part of everyday Anglo-Saxon life. This paper examines a range of original sources that reveal the ways in which the teachings and practices of Christianity and Christians were part of that acceptance.

Sometime in the fifth century, after the Romans had abandoned Britain, Anglo-Saxon raiders from across the North Sea turned their raids into conquest and settlement and founded a society based on a triple division: nobles, freemen and slaves. ${ }^{1}$ To this society in the year 597 came Augustine of Canterbury, sent by Pope Gregory the Great to convert the Anglo-Saxons to Christianity. By the end of the seventh century, Christianity had spread across England. The introduction of Christianity, however, had little effect on the institution of slavery. Although Anglo-Saxon Christians were aware of "the sadness of servitude and the joy of freedom," their society incorporated slavery as an ordinary, natural part of life; the teachings and practices of their church show how deeply slavery was embedded in everyday life and thought. ${ }^{2}$

Recent scholarship on early medieval slavery has focused on two problems: first, conceptual issues and terminology involving general ideas of servitude and coerced labour; and second, when, how, and why slavery yielded to serfdom. Ruth Mazo Karras, for instance, concentrates on the construction of the categories of freedom and unfreedom and why Scandinavian society needed such categories. Pierre Bonnassie examines the process through which serfdom replaced slavery. ${ }^{3}$ Wendy Davies,

${ }^{1}$ Dorothy Whitelock, "Introduction," in English Historical Docroments, volume I, c.500-1042, $2^{\mathrm{d}}$ ed., ed. Dorothy Whitelock (London: Eyre Methuen, 1979), 52; David A.E. Pelteret, Slavery in Early Mediaeval England (Woodbridge, Suffolk: The Boydell Press, 1995), 32.

${ }^{2}$ Brihtwold, "Letter of Brihtwold, Archbishop of Canterbury," in English Historical Documents, 794.

${ }^{3}$ Ruth Mazo Karras, Slavery and Society in Medleval Scandinavia (New Haven, CT: Yale University Press, 1988); Pierre Bonnassie, From Slavery to Feudalism in South-western Europe, trans. Jean Birrell (Cambridge: Cambridge University Press, 1991).

Past Imperfect, Vol. 9, 2001-2003, pp. 25-42 
however, recasts the question as "what, exactly, changed?" The role of the church, once presented as central to the disappearance of slavery, has been pushed aside. ${ }^{5}$ How slaves and slavery functioned for centuries as an integral part of mundane activities and interactions has attracted less study, apart from Pelteret's survey of late Anglo-Saxon England. ${ }^{6}$

Although slaves were numerous in Anglo-Saxon society, they make only fleeting appearances in documents. Literature such as poetry and epics dealt with a warrior society and was produced for warriors who wanted to hear of their own glorious deeds, untarnished by the intrusion of people believed to be incapable of the high virtues of courage and generosity. ${ }^{7}$ Most surviving documents such as wills, charters, law codes, and hagiography mention slaves only in passing, usually as the object of action by someone else, such as a testator seeking passage to heaven or a saint displaying his holy virtues. Manumissions provide clear evidence of slavery, but in a formulaic manner that conceals thoughts and motivations. Rules for behaviour, whether law codes or penitentials, are more helpful, with a few precious documents indicating awareness of a slave's feelings.

Examples from a variety of documents are examined here in an attempt to show something of the church's involvement in the institution of slavery and its attitudes toward it; that is, what people did as well as what they thought. Such evidence is available for a period spanning the fifth to the eleventh centuries. Seven centuries, however, is a long time to treat as a unit without allowing for considerable change, ${ }^{8}$ yet the evidence is so sparse that it is difficult, indeed misleading, to attribute the differences between two documents to chronology rather than to location, or simply to variation, within a complex society. Accordingly, documents examined in this study are grouped by type rather than by date.

Any Anglo-Saxon alive at the time of the Norman invasion might reasonably have responded with incredulity if told that slavery would soon disappear from England, so familiar were slaves to this society. The three broad divisions of Anglo-Saxon society as it took shape in

\footnotetext{
${ }^{4}$ Wendy Davies, "On Servile Status in the Early Middle Ages," in Serfdom and Slavery: studies in legal bondage, ed. M.L. Bush (London: Longman, 1996), 225-246, especially 232.

${ }^{3}$ See, for instance, Bonnassie, From Slavery to Feudalism, 5-6 and 25-32.

${ }^{6}$ Pelteret, Slavery in Early Mediaeval England.

${ }^{7}$ Pelteret, Slavery in Early Mediaeval England, 53.

${ }^{8}$ Although Whitelock suggests "the main structure [of Anglo-Saxon society] is constant." Whitelock, "Introduction," 52.
} 
sixth-century England were nobles, freemen, and slaves. The AngloSaxons had not, of course, introduced slavery into Britain; it had existed under the Romans and Celts. As Roman control broke down, however, the island itself became a source of slaves, seized in raids by Saxons, Scots, and Irish. St. Patrick is perhaps the most famous example, but far from the only one. Raiding and trading continued after the Anglo-Saxons took control of much of the island. Bede's account of Pope Gregory the Great's encounter with Anglo-Saxon boys in a Roman slave market may be legendary, but it was believable to Bede's audience. ${ }^{9}$ Moreover, in one of his own letters, Gregory ordered his priest, Candidus, who was travelling in Gaul, to purchase Anglo-Saxon youths and to have them educated in monasteries. ${ }^{10}$ Bede's story of the captive thegn Imma refers to a slave market in London and to Frisian traders who bought slaves for export. " Many of those captured in England were sold abroad, including a girl who became queen of France, Balthild, and the nameless slaves whom she in turn bought. ${ }^{12}$ Balthild engaged in Christian charity by buying her countrymen and giving them to God, and she evidently found many such slaves ready to hand.

Imma's story shows, too, how warfare, endemic in England, first between tribes and then between emerging kingdoms, provided a steady supply of slaves for centuries after the arrival of the Anglo-Saxons. Furthermore, the boundary between the Celts and the Anglo-Saxons was long contested. The mutual relations of Celt and Saxon are shown by the way the word 'wealh' changed in meaning from Celt or Welsh to slave. ${ }^{13}$ When the Anglo-Saxons gained the upper hand at the end of the eighth century, the Vikings attacked from Northumbria to Devon and everywhere in between, raiding, trading and seizing, using, and selling slaves. The strife eased at the end of the ninth century, when Alfred fought the Danes to a standstill, but flared again when the Danes returned at the end of the tenth century, first under Sweyn Forkbeard and then under his son Cnut. The resulting chaotic conditions supported a continuing slave trade.

\footnotetext{
${ }^{9}$ Bede, Historia Ecclesiastica, ed. and trans. J.E. King (London: William Heinemann Ltd, 1930), IV.22.

${ }^{10}$ Pope Gregory I, "Letter of Pope Gregory I to Candidus," in English Historical Documents, 787.

"Bede, Historia Ecclesiastica, IV.22.

12 Patrick J. Geary ed.,"Life of St. Balthild," in Readings in Medieval History volume I: The Early Middle Ages, ed. Patrick J. Geary (Peterborough, ON: Broadview Press, 1998), 154.

${ }^{13}$ Karras, Slavery and Society in Medieval Scandinavia, 30.
} 
Even in nominally peaceful times, raiders were active. The story of St. Guthlac is instructive. ${ }^{14}$ Late in the seventh century, at the age of fifteen, Guthlac gathered a band of youths around himself; for nine years, he led them in a life of fighting and raiding. Guthlac earned the approval of his Christian biographer because he returned to his victims one third of his takings. ${ }^{15}$ Slaves are not specifically mentioned as part of Guthlac's booty, but the usual objects of a raid were movable goodsmoney, provisions, animals, and people. Guthlac's and Imma's stories show how slave-raiding and warfare made sudden, violent enslavement a threat to everyone.

Slaves were created in other ways as well. Many people were born into slavery. Law codes set slavery as the punishment for various offences such as working on Sunday or some cases of theft; slavery in these instances functioned as a de facto prison. ${ }^{16}$ Evidence that such slaves were common is abundant, not merely because law codes explicitly stated such a penalty, but because wills sometimes singled out penal slaves for grants of freedom. ${ }^{17}$ In addition, economic hardship often led to slavery. In times of penury, a father might sell a child, and whole families could end up as slaves as an alternative to starvation. Thus, in a tenth-century manumission document, Geatflæd freed "all those persons whose heads she took in exchange for their food in those evil days." ${ }^{18}$ Birth, punishment, and poverty, together with war and raids, maintained the supply of slaves in Anglo-Saxon society.

The matter-of-fact acceptance of slavery and its incorporation into society is visible in the customs and practices of everyday life. The numerous law codes produced by Anglo-Saxon rulers and the penitentials that circulated among the clergy provide insight not only into what Anglo-Saxons were doing, but also into what the authorities thought they ought, or, more commonly, ought not to be doing. The laws and penitentials, that is, are both descriptive and prescriptive, revealing attitudes and actions in brief, often incomplete, glimpses. Moreover, because these codes often name specific penalties, some measure of the importance attached by contemporaries to each transgression may be inferred.

${ }^{14}$ Felix, "Life of St. Guthlac," English Historical Documents, 770-775.

is Bbid., 771.

${ }^{16}$ The Laws of the Earliest English Kings, ed. and trans F.L. Attenborough (New York: Russell \& Russell Inc., 1963), Ine 3.2, 37, and Ine 7.1, 39.

${ }^{17}$ For instance, "The Will of Flfwold," English Historical Documents, 580-1. 18 "An Old English manumission from Durham," English Historical Documents, 563. 
Penitentials were, of course, produced by and for members of the church. The link between surviving law codes and Christian teachings is less obvious, but churchmen were prominent in government and influenced the law from the time they first arrived in England. The earliest code, Æthelberht's, written just five or six years after Augustine landed on the coast of Kent, included in its first provision rules about compensation for theft of church property. ${ }^{19}$ Furthermore, preambles to law codes often included references to churchmen among the king's advisors. Wihtred of Kent, for instance, enacted a set of laws in about 700. Its preamble states:

there was assembled a deliberative council of the nobles. There were present Berhtwald, the chief bishop of England, and the abovementioned king; the bishop of Rochester, who was called Gefimund; and every order of the Church of the province expressed itself in unanimity with the loyal laity. There the notables, with the consent of all, drew up these decrees and added them to the legal usages of the people of Kent. ${ }^{20}$

Churchmen here constitute an important part of the ruling group. In this preamble, the archbishop is named before the king, and the other churchmen appear before the rest of those present, who are identified simply as the laity, not as the important men of the country. ${ }^{21}$ The penitentials, documents in which churchmen expressed their concerns about the consequences of sin for the individual, rarely mention slaves. To the churchman, a Christian was a Christian, at least in theory, and what was a $\sin$ for one was a sin for all. Nevertheless, the circumstances of the sin and of the sinner had to be considered. The introduction to the so-called penitential of Bede explicitly acknowledges this: "for not all are to be weighed in one and the same balance, although they be associated in one fault."22 There follows a long list of factors that must be taken into consideration in assigning penance. Social status was included as an important part of a Christian's identity, as were such

${ }^{19}$ Attenborough, The Lows, Ethelberht 1, 5.

${ }^{20}$ Attenborough, The Laws, 25.

${ }^{21}$ Of course, the codes and meetings were recorded by the clerics, not by the laity.

${ }^{22}$ Medieval Handbooks of Penance, eds. and trans. John T. McNeill and Helena M. Gamer (New York: Columbia University Press, 1938), 223. 
things as economic status, age, gender, or church rank (layman, cleric, bishop, deacon and so on). ${ }^{23}$

Practical application of such considerations can be seen in Bede's penitential in some of the penances assigned for killing. Killing with premeditation or for gain, for example, was worse than killing by accident (four years penance versus one.) ${ }^{24}$ In particular, killing at the command of a master was more serious for a freeman than for a slave. The slave had to perform only forty days penance, while the freeman had to do one year's worth, plus intervals for the next two years. The penalty assessed against the slave was, in fact, the same as that levied against anyone who killed in warfare. ${ }^{25}$ Since killing in war was sanctioned by social custom, the penitential required only that the soldier who killed in combat purify himself; in short, penance here involved ritual cleanliness rather than sin. Since the slave killing at his master's command received the same forty day penalty, the church seems to have been stating that he was not responsible for his actions and had no guilt for which to atone. The slave in this case was treated as an instrument wielded by the will of another.

In Theodore's penitential, put together in the late seventh century, the penance done by a man who had intercourse with a woman other than his wife depended upon the status of the woman and not that of the man, which seems to contradict the requirement to consider the sinner. The status of the victim was here more significant, in a manner specifically reminiscent of Anglo-Saxon law codes. If the intercourse involved a virgin, the sinner had to fast for one year; if a vowed virgin, three years. If the sinner involved his own slave, he had to fast for six months, apparently a lesser penalty, but he also had to set her free, an economic penalty for him and an odd provision in a list that consists primarily of specified periods of penance. ${ }^{26}$ Nevertheless, whatever the church's intention (probably the control of fornication and, in this case, the removal of opportunity), the result was that the slave woman was protected from sexual service and might even acquire her freedom. The slave, in effect, received compensation for a wrong done her, again the sort of penalty more commonly found in the law codes than in penitentials, which were concerned with reconciling the sinner with God. Although the church again treated the slave as the object or instrument of

\footnotetext{
23 Ibid., 223.

${ }^{24}$ Ibid., II.2, 224 and II.5, 225.

${ }^{25}$ Bbid., II.7 and II.6, 225.

${ }^{26}$ Ibid., Book I, XIV.10-12, 196.
} 
her master's sin, his punishment brought her a material and social benefit. Church teaching thus indirectly assisted the slave.

Other church rulings, again from Theodore's penitential, attempted to deal with problems created by endemic warfare and slave raids in one area of the church's special interest, marriage. Worry about the sin of fornication overrode concern for the sanctity of marriage. In brief, individuals whose spouses had been taken into captivity and could not be ransomed, or did not return, might marry again, sometimes with a waiting period of one year or of five years specified. ${ }^{27}$ The newly-made slave had a period of grace before being recognised as officially dead. If the missing spouse subsequently returned, problems arose about what should be done with the new spouse and how the old one should be reintegrated into society. Such returns must have occurred often enough that we have more than one ruling on the matter; one mentions slaves from overseas, implying that even those sold far from home might through luck or ingenuity make their way back. ${ }^{28}$ The penitential gives two contradictory answers-keep the old spouse, keep the new spouse. ${ }^{29}$ The two different answers suggest either that the return of a captive was so rare that isolated cases led to ad hoc solutions, or that different groups adopted different solutions in customs strong enough (that is, frequent enough) to withstand the influence of other ways. The church was not always consistent in its attempts to cope with the realities of medieval life, marriage, and slavery.

A particularly interesting provision in Theodore's penitential states that the wife of a penal slave may find herself another husband after a year. ${ }^{30}$ Here, the church recognised the distaste felt for slavery and permitted escape from contact with it (for the wife herself in this case was not a slave), even though this escape represented a failure to uphold the sanctity of marriage. The church and the wife were treating the slave as if he were dead, an impression reinforced by the next provision, which allowed a widow to take a new husband one year after the death of her previous one, precisely the same waiting period. ${ }^{31}$ The first ruling, however, was addressed to the free spouse and allowed the rest of a slave's family to proceed with their lives. In other words, in order to accommodate the realities of slavery, the church was willing-or was forced-to modify its customary insistence on the sanctity of marriage.

\footnotetext{
${ }^{27}$ Bbid., Book II, XII.21-25, 210.

${ }^{28}$ Ibid., Book II, XII.25, 210.

${ }^{29}$ Ibid., Book II, XII.23 and XII.25, 210.

${ }^{30}$ bid., Book II, XII.9, 209.

${ }^{31}$ Ibid., Book II, XII.10, 209.
} 
Here too, consistency in church teachings was compromised by the church's acceptance of slavery.

Laws proclaimed by kings and their advisors also took account of the slaves within society and, moreover, recognised a slave's dual character as property and as a responsible person. The laws are, to us, an odd mixture, containing rules directed to clerics, rules touching on religious rights and duties, and penalties for crimes. In Æthelberht's code, written in 602 or 603, slaves were among the social ranks taken into account in the laws that regulated compensation for injury. For instance, if any man lay with one of the king's grinding slaves, he had to pay the king twentyfive shillings. If, however, the slave was of the third class, he had to pay only twelve shillings. ${ }^{32}$ Violation of a nobleman's serving maid cost twelve shillings, of a commoner's, six shillings. A commoner's secondclass slave cost fifty sceattas and a third class slave, twenty sceattas. ${ }^{33}$ In a society where wergeld reflected and displayed status, such monetary compensations make a double status system clear. Even the lawmakers, nobility, and clergy recognised the status of the slaves within a slave hierarchy as well as the status dependent on that of the owner.

At the same time, laws both held slaves responsible for their own actions and extended protection to them. A slave who stole had to pay twice the value of the stolen goods in compensation. ${ }^{34}$ On the other hand, the freeman who stole from a freeman had to pay three times the value of the stolen goods. ${ }^{35}$ The slave then had means of his own with which to pay a fine but could not be expected to pay as much as a free man. If a slave was robbed on the highway, there was a set fine of three shillings. ${ }^{36}$ The laws again reflect the status of both victim and offender, but all offenders were considered responsible for their behaviour, and everyone, slave and free, received the protection of the king's peace.

Some hundred years later, Wihtred of Kent issued another set of laws. They are quite brief, only twenty-eight in number, but again contain several references to slaves. The ceremony that granted freedom to slaves at the altar was declared effective, but the emancipator took the freedman's heritage and wergeld and guardianship of his household, wherever the freedman might be. ${ }^{37}$ The law thus provided freedom with

\footnotetext{
32 Attenborough, The Laws, Ethelberht 11, 5.

${ }^{33}$ Bid., Ethelberht 14 and 16, 7. Twenty sceattas equalled one Kent shilling at this time.

${ }^{34}$ Ibid., The Laws, Fthelberht 9, 5.

${ }^{35}$ Ibid., The Laws, Ethelberht 90, 17.

${ }^{36} \mathrm{Ibid}$., The Lanws, Ethelberht 89, 17.

${ }^{37}$ Bbid., The Laws, Wihtred 8, 27.
} 
considerable obligations and restrictions, but, by putting the ex-owner in the place of kin, it also provided the new freedman with a place in society, an arrangement essential in a society where all men needed to be able to bring others to vouch for them in any legal proceedings. By allowing freedom to be given at the altar, however, the church gave its authority and approval both to the legal act of manumission and to the social structure that gave rise to such acts.

Wihtred also enacted laws pertaining to church teachings. The first group dealt with work on Sunday. Slaves who worked on that day against their masters' orders, or who travelled on their own business, had to pay their lords a fine. ${ }^{38}$ Here, the church was implicitly claiming jurisdiction, through royal laws, over another man's property, even if the fine went to the lord. If a freeman was caught working on a Sunday, half the fine went to the informer. ${ }^{39}$ But someone who informed on a slave (unless it was the master, who was presumably then exposing himself to ridicule or sanctions for failing to control his slaves) gained nothing. Interesting, too, are the assumptions that slaves might have enough money or possessions to pay six shillings, a substantial sum, and that they might make journeys for their own purposes. The church also penalised slaves, not their masters, if the former made offerings to devils or ate meat on fast days, again to the sizable sum of six shillings. ${ }^{40}$ Both the church and the king's law recognised slaves as people who could make their own choices, at least in some things, and who had their own possessions and affairs.

Sunday work appears again in Ine's code, written at the end of the seventh century. If a slave worked on Sunday without his master's knowledge, the punishment was flogging or a fine (probably thirty shillings). The slave was held responsible as a person able to make choices. If, however, the master ordered the work, the master paid the fine, and the slave was freed. ${ }^{41}$ Here the slave is presented as having no choice, and here again, the church interfered between master and slave. Furthermore, although the second law was probably directed against the

${ }^{38}$ Ibid., The Laws, Wihtred 9 and 10, 27.

${ }^{39}$ Ibid., The Laws, Wihtred 11, 27.

${ }^{40}$ bid., The Laws, Wihtred 13 and 15, 27.

${ }^{41} \mathrm{Ibid}$., The Laws, Ine 3 and $3.1,37$. It is reasonable, surely, to wonder how often the law was applied. Even if so august a figure as the king or a bishop saw the slave working when he should not and brought the case to court, how was the slave to prove he was working at his master's orders? Witnesses, sufficiently important that the master could not overawe them, would be necessary for the ordering as well as the work. 
master, the slave received a boon, freedom. Nevertheless, the church was not opposing slavery or even taking advantage of an opportunity to free an individual slave, because the freeman found working on Sunday of his own choice either paid a huge fine of sixty shillings or was reduced to slavery. ${ }^{42}$ The church in these cases was manipulating the institution of slavery to enforce its own rules.

Reduction to slavery, a condition that involved forced labour, may seem particularly appropriate for a crime involving the misuse of labour, that is, work on Sunday. In fact, it was a common penalty for various crimes. Another provision in Ine's laws made slavery the punishment for certain cases of theft. An entire household could be enslaved, for instance, if its members knew that the head of the household was stealing something. ${ }^{43}$

Another group of laws reveal continuing ties of kinship between slave and freeman. One such law forbade the selling overseas of any slaves who were countrymen:"If anyone sells one of his own countrymen, bond or free, over the sea, even though he be guilty, he shall pay for him with his wergeld and make full atonement with God. ${ }^{, 44}$ Ross Samson suggests that such laws were economic, comparable to laws forbidding the export of cattle or grain in times of dearth, and that they were intended to keep a scarce resource at home. ${ }^{45}$ Yet, if this is correct, the phrase "of his own countrymen" should not be present, for all slaves would be valuable as workers. Rather, the phrase suggests continuing ties to and responsibility for one's fellows, even distantly connected slaves. This interpretation is reinforced by another law in which Welsh slaves are compared to English slaves. An oath equivalent to twelve hides was good enough to procure the whipping of a Welsh slave, but the whipping of an English slave required almost three times as much, thirty-four hides. ${ }^{46}$ The local slave, that is, was never wholly cut off from the community of his kinfolk, those others who had some putative connection to him.

${ }^{42}$ Bbid., The Laws, Ine 3.2, 37.

${ }^{43} \mathrm{Bid}$., The Laws, Ine 7 and 7.1, 39. If he stole without the knowledge of the rest of the household, then he paid a stiff fine, and they were not punished. ${ }^{44} \mathrm{Ibid}$. The Laws, Ine, 11, 41.

${ }^{43}$ Ross Samson, "The End of Early Medieval Slavery," in The Work of Work: Servitude. Slavery and Labor in Medieval England, eds. Allan J. Frantzen and Douglas Moffat (Glasgow: Cruithne Press, 1994), 118.

${ }^{46}$ Attenborough, The Laws, Ine 54.2, 55.

${ }^{47}$ Bonnassie states that increasing numbers of slaves such as these, with local ties that helped erase the differences between free and slave, contributed to the decline of slavery and its replacement by serfdom. The process must have been very slow, however, since Ine's laws were enacted around 700 and slavery did 
Another law is also suggestive of continuing ties. If a penal slave was killed, his wergeld was not paid to his kin if they had left him unransomed for more than a year. ${ }^{48}$ In this case, slavery extinguished ties of kinship, but only after the kinfolk had been given a chance to exercise them. Yet another law states that a freeman was not required to have anything to do with a relative who was a slave, but that he could, if he chose, protect him from feud. On the other hand, the slave was also able to distance himself from his free kinsmen, perhaps so that he need not contribute to a ransom or wergeld or otherwise take responsibility for his kin. This law is worth quoting: "A freeman need not associate himself with a relative who is a slave, unless he wishes to ransom him from a vendetta; nor need a slave associate himself with a relative who is a freeman." 49 The situation seems very odd, because the slave not only had kin by blood, he had the upper hand in refusing to honour the relationship. That is to say, if the slave was "natally alienated," as Orlando Patterson puts it, it was by his own and not his master's choice. $^{30}$ But the mere existence of this law, phrased in this way, suggests that a slave could retain free kin and was even expected to contribute to their payment of a wergeld, for the law is found in that context. A slave might remain part of the community in his own right; he had legal ties to people other than his master.

Alfred's laws, issued at the end of the ninth century, made provision for four Wednesdays during Ember weeks on which slaves might sell their possessions, either gifts or their own products. ${ }^{51}$ A few years later, Edward and Guthrum also regulated work on church festivals. The freeman who transgressed was fined or enslaved, while the slave was fined or whipped. ${ }^{32}$ Here, again, almost three hundred years after Fthelberht, is the implication that slaves had a right to own things and to have free time to use as they saw fit. Anglo-Saxon laws imply a regular source of income for slaves, readily available for fines. Here, too, are kings, and clergy through the kings, telling masters how they can use their property. Again, enforcement may have been difficult, but the slave-master relationship was subject to interference in its very basics:

not disappear for several centuries. Bonnassie, From Slavery to Feudalism, 34 37.

${ }^{48}$ Attenborough, The Laws, Ine 24.1, 45.

${ }^{49} \mathrm{Bbid}$., Ine 74.2, 61 .

${ }^{50}$ Orlando Patterson, Slavery and Social Death (Cambridge, MA: Harvard University Press, 1982), 7-8.

${ }^{51}$ Attenborough, The Laws, Alfred 43, 85.

52 Ibid., Edward and Guthrum 7.1, 107. 
the master could not tell the slave when to work. The master who forced the slave to work on Sunday, however, was merely fined; he no longer had to free the slave. ${ }^{53}$ Perhaps over three centuries that provision proved unworkable.

The prevailing legal approach to slavery can be seen in a sermon delivered by Wulfstan, archbishop of York, in about 1014, during a Danish invasion. Wulfstan was bishop of London from 996 to 1002 and then archbishop of York and bishop of Worcester until his death in 1023. Like all senior clerics, he took part in the royal administration. He drafted law codes for both Fthelræd II and Cnut that emphasised a stratified society in which all members faithfully carried out the duties appropriate to their social status. In his Sermo Lupi ad Anglos, Wulfstan deplored the sinful state of England, which led to invasion and suffering. ${ }^{54} \mathrm{He}$ lamented the lack of respect for the rights of others, complaining that slaves' rights were being ignored and that many people had wrongfully been sold into slavery and even sent overseas, sometimes by their own families. ${ }^{35} \mathrm{He}$ was deeply shocked that runaway slaves had not only been accepted into the Danish army, but achieved a greater social status and received more honour than their former masters. ${ }^{56}$ To the legally-minded Wulfstan, a well-ordered society was one in which all members, including slaves, respected the rights of all others, again including slaves, and were content with their own lot. At the same time, Wulfstan implied that people suffered when they were wrongly enslaved and deprived of freedom.

Freedom was seen as something to cherish and hence a gift worth giving-and it was given, frequently, but only to individuals or carefully limited groups. Nobody seems to have taken the next step and advanced the notion of freedom as a general right. But how could they have done so? Not only were slaves a part of everyday life, but people, including those of the highest rank, thought of themselves as slaves to God. A common way for a high church official to refer to himself when beginning a letter was 'servus servorum Dei,' usually translated as 'the servant of the servants of God,' but in Latin, carrying the force of 'the slave of the slaves of God.' Gregory the Great used this greeting, as did Boniface, Honorius, and Vitalianus in letters recorded by Bede. ${ }^{57}$ One

\footnotetext{
${ }^{33}$ Ibid., Edward and Guthrum 7.2, 107.

${ }^{34}$ Wulfstan of York, "The Sermon of "Wolf' to the English," in Anglo-Saxon Prose, ed. and trans. Michael Swanton (London: Dent, 1975), 116-122.

${ }^{35}$ Bid., 117-118.

${ }^{56}$ Bid., 119.

${ }^{57}$ Bede, Historia Ecclesiastica, I.23, II.10, II.17, III.29.
} 
referred to a fellow churchman, moreover, as servus Dei. Even while complaining about upstart slaves, Wulfstan referred to churchmen as "Godes theowa," God's slaves. ${ }^{58}$ The topos was common and derived its impact from shared beliefs regarding the position of a slave in society, the relation of slave to master, and the gradations in the slave's honour and status, dependent upon closeness to the master and the master's status. Furthermore, when such people spoke of themselves as God's slaves, they may have meant it literally, considering themselves bought and paid for and therefore just as much bound to God as any ordinary slave was to his human master. When Wulfstan said that Christ bought us with a costly price, he meant His life-blood in the literal, not figurative sense.

The laws of Ine give further evidence of how churchmen saw their relationship with God. Ine refers to his advisors as a great concourse of the servants of God, Godes theowa. ${ }^{60}$ Theowa was the word for slaves and appears frequently in the body of laws with that meaning. ${ }^{61}$ The Anglo-Saxons saw no disrespect or dishonour in referring to clerics as slaves of God.

Nevertheless, freedom from earthly masters was cherished. Two poignant examples of the high value placed on freedom survive, one in a letter and the second in a textbook. In about 710, the archbishop of Canterbury wrote to the bishop of Sherborne, begging him to intervene in the ransoming of a captive so that she might spend the rest of her life with her kinsmen "non in servitutis tristitia sed in libertatis...laetitia," "not in the sadness of servitude, but in the joy of freedom." archbishop offered no reward to the bishop, only the knowledge that, by helping, he might bring joy to someone who was a slave. Almost three centuries later, Abbot Elfric of Eynsham wrote a colloquy to instruct young students in simple Latin and in the variety and value of earthly

\$8 "Sermo Lupi ad Anglos,"

http://cif.rochester.edu/ mjbernst/wulfstan/noframes.html.

s9 Wulfstan, "The Institutes of Polity," in Anglo-Saxon Prose, 138; on literal interpretations, see Thomas Rendall, "Bondage and Freeing from Bondage in Old English Religious Poetry," Journal of English and Germanic Philology 73(1974): 499.

${ }^{60}$ Attenborough, The Laws, 36-37.

${ }^{61}$ Attenborough, The Laws, in passim, for instance, Ine 3 and 3.1, 37.

${ }^{62}$ Brihtwold, "Letter of Brihtwold," in English Historical Documents, 794. For the Latin, Arthur West Haddan and William Stubbs, Councils and Ecclesiastical Documents relating to Great Britain and Ireland volume III (Oxford: Clarendon Press, 1869-78), 284. 
trades. ${ }^{63}$ One of the most important workers was the ploughman, who helped feed them all. When the teacher in the dialogue says to the ploughman that the work must be hard, the ploughman replies "Etiam, magnus labor est, quia non sum liber," "the work is hard, because I am not free." ${ }^{24}$ The work would be no less demanding physically if the ploughman were free, but the burden of slavery was presented as the preeminent source of sorrow. These two brief statements speak to the happiness that is found in freedom.

Perhaps the recognition of such feelings and the pity thereby evoked are part of what made manumission a pious act. Early in the tenth century, following the advice of his clerics, Ethelstan issued an ordinance to all his reeves that, for the good of Ethelstan's soul, each reeve should perform deeds of charity, including the freeing of one penal slave each year. ${ }^{65}$ The release was linked to Fthelstan, not to the deserts of any particular slave, not even to any particular sort of slave-thief, murderer, or Sunday worker. The freeing of slaves was seen as a pious act, useful for Ethelstan's salvation. Any justification of slavery as a result of $\sin$ in general or in particular would still apply, because the reeves were not directed to select innocent or deserving slaves. Any penal slave would do.

The occasional random release of a slave may have kept slaves under control by giving hope of freedom, but the act of manumission was not presented in that way. Samson suggests that the act was part of giving away one's possessions and that the giving was what mattered; who benefitted was immaterial. ${ }^{66}$ No consideration for the recipient need be involved, because the sinner's problem lay not in having slaves but in having any possessions at all. But other provisions for charity in the same ordinance specifically directed the reeves to feed and clothe an indigent Englishman for a year. ${ }^{67}$ If the intent was only to reduce possessions, the king could have given gifts to his warriors or to the church or, for that matter, thrown his money into the nearest lake. Acts of charity such as Æthelstan's, however, were not random divestitures of possessions. Instead, they had a deliberately chosen object and purpose: to help the wretched. To that end, money and land could be given to the church, alms to the poor, or freedom to slaves. Pity was an important part

${ }^{63}$ Elfric, Abbot of Eynsham, Alfric 's Collogıy, ed. G.N. Garmonsway (Exeter: University of Exeter, 1978).

${ }^{64}$ Bbid., 21.

${ }^{65}$ Attenborough, The Lavis, Ethelstan, Ordinance 1, 126.

${ }^{66}$ Samson, "The End," 109.

${ }^{67}$ Attenborough, The Lavis, Ethelstan, Ordinance 1, 126. 
of piety, and both were enjoined by the church in response to the ideas expressed by Christ when he said "inasmuch as ye have done it unto one of the least of these my brethren, ye have done it unto me."68 The church recognised that slaves qua slaves needed help and that the proper expression of that aid was the gift of freedom.

The motive of piety is to the fore in wills in expressions such as "for my soul's sake" or "for my wife's or parents' sake." simply getting rid of possessions cannot hold here either. The dead had no possessions. The praiseworthiness of the act therefore had to include the choice of recipient. Just as giving to the church was praiseworthy because it was the church, so, once again, giving to a slave was praiseworthy because he was a slave. And just as food and money were desired by the beggars who received the alms distributed in wills, so was freedom desired by slaves. That choice of gift for slaves in turn implied recognition that to be a slave was to suffer. Pity and piety again went together, and, insofar as the church promoted such acts, it was recognising that, for any individual, slavery brought sorrow.

One remarkable will, written about 990 , displayed the giver's piety, her practicality, and her knowledge of her slaves. ${ }^{10}$ Ethelgifu carefully divided her extensive possessions-land, slaves, livestock, and movable goods-among several recipients, including church establishments, relatives, and dependents. She identified over one hundred slaves by name, freeing some and bequeathing others. More than sixty slaves, two specified households, and two specified sets of children were freed. She was not just freeing the old as a reward for long service, for many of the younger generation were released. For instance, "[a]t Gaddesden Edmund and his son and Heahulf and Eadwig are to be freed; Athelwine and his wife are to be given to Æthelstan and their children are to be freed."11 At the same time, she kept slaves essential to running the estates: "and Eadstan the swineherd is to be freed and his son is to have charge of the herd and the family otherwise is to be freed."12

Other interesting points about the connections between the church and slavery appear in Æthelgifu's will. Her priest, Edwin, received his

\footnotetext{
${ }^{68}$ Matthew 25:40.
}

${ }^{69}$ Dorothy Whitelock, Anglo-Saxon Wills (Cambridge: Cambridge University Press, 1930), passim, Athelgifu.

${ }^{70}$ Ethelgifu, "Chapter II: The Text and Translation of the Will," in The Will of Athelgifu, ed. and trans. Dorothy Whitelock (Oxford: Oxford University Press, 1968), 5-17.

${ }^{71}$ Bid., 6.

${ }^{72}$ Bid., 8. 
church, two women and their children-and his freedom. ${ }^{73}$ Slaves ordained as priests were not thought to have been a problem in the Anglo-Saxon Church before this will came to light, for no other slavepriests are known and there are no known Anglo-Saxon laws forbidding the practice. But Ethelgifu's gift to Edwin shows that in England, too, the church found itself with priests who were slaves and so served two masters, one human, the other divine. Fthelgifu also freed three women, Elfwaru, Leofrun, and Ethelflæd, on condition that they recite four psalters each week for a month and one each week for a year after that. ${ }^{74}$ Whitelock suggests that this stipulation implies that the three slave women had received some education, perhaps in order to participate in the religious life of a home nunnery. ${ }^{75}$ On Ethelgifu's estate, slaves participated fully in church life, to the point of carrying out official duties.

Churchmen freed other slaves as part of their mission to convert and teach. Wilfrid, for instance, when given the island of Selsey complete with all its fields and slaves, first baptised the slaves and then set them free. Bede compared the release from bondage to a man to release from bondage to the devil. ${ }^{76}$ Wilfrid, he said, brought both inward and outward benefits to his new converts. Freedom served as a sign and a reminder of God's grace. This interpretation is strengthened by another of Bede's stories about Wilfrid's activities in Sussex. Wilfrid baptised other South Saxons and taught them to fish, thus freeing them from the threat of starvation, and again brought both invisible and visible gifts. He won them to Christianity, Bede says, because they understood that God had given them grace for both their bodies and their souls. ${ }^{77}$ In these two stories, the condition of the slave was treated as parallel to that of the poor and hungry. For slaves, the appropriate earthly sign of God's grace was release from slavery.

Wilfrid's gift of freedom was a means to an end, intended to show God's goodness and to lead men to Him. Freedom acquired through a miracle worked in a similar manner, displaying God's power and a saint's holiness. For instance, the thegn Imma was captured in battle, put

\footnotetext{
${ }^{73}$ Ibid., 8.

${ }^{74}$ Ibid., 8.

${ }^{75}$ Whitelock, "Chapter III: Examination of the Will," in Will of AEthelgifu, 1837.

${ }^{76}$ Bede, Historia Ecclesiastica, IV.13: "Quos omnes ut baptizando a servitute daemonica salvavit, etiam libertate donando humanae ingo servitutis absolvit." "Ibid., IV.13: "Eum, qui verus est Deus, et interioribus se bonis et exterioribus caelesti gratia ditasse."
} 
in chains, and sold to a slave-trader. ${ }^{78}$ Imma's fetters, however, continually fell off whenever his brother, a priest, said a mass for him. Imma was therefore given permission to ransom himself and so regained his freedom. A bondwoman, chained and sentenced to flogging for a small fault prayed to St. Swithin. ${ }^{79}$ The bonds on her feet fell off, and she ran to St. Swithin's church. Her master found her there, unbound her hands, and freed her in honour of the saint.

Miracles leading to freedom for a slave were tricky. The sick were easier to help, because if a saint cured a lame man, the cure was obvious to all and directly affected no-one but the lame man. Help for prisoners, too, was straightforward; they were visibly freed when chains fell off or locked doors sprang open. Physical afflictions and barriers were physically removed. But a slave's chains were invisible, because he was held by a legal bond, which, moreover, involved a third party, the master. A saint could no more say to the master "your slave is now free" than he could say "this land or that cow is no longer yours." The saint had to convince-or force-the master to remove the legal bond. A legal problem demanded a legal remedy. The physical miracles were merely one step in a sequence that had to be completed through the master's acknowledgement of the slave's new freedom. If the church and its saints wanted to make someone truly free in the minds of onlookers, they had to work within the laws of society and slavery.

Some fifty years after Wulfstan preached his sermon to the English, the Normans conquered the country and overthrew the Anglo-Saxon social hierarchy. There was, however, an epilogue to the church's involvement in Anglo-Saxon slavery. Another Wulfstan, also bishop of Worcester and the last of the Anglo-Saxon bishops, taught that it was a sin for men to sell people of their own blood. ${ }^{80}$ Before his death in 1095, he managed, through persistence and preaching, to shut down the slave market in Bristol. Wulfstan's success, claims his biographer, was an example for all England.

And perhaps it was. In 1102, a council at Westminster forbade all slave-trading in the country. The councillors this time made no reference to countrymen or even to fellow Christians, only to the shameful practice of selling people: "illud nefarium negotium quo hactenus homines in

\footnotetext{
${ }^{78}$ Ibid., IV.22.
}

79 Elfric, abbot of Eynsham, Alfric's Lives, ed. Walter W. Skeat (London: Early English Text Society, 1881), 453.

${ }^{80}$ William of Malmesbury, The Vita Wulfstani, ed. Reginald R. Darlington (London: Royal Historical Society, 1928), II.20. 
Anglia solebant velut bruta animala venundari." ${ }^{81}$ Although slavery itself was not forbidden, within a few decades it had vanished from England so completely that the very word theow and all its derivatives disappeared from the English language. At the end of the Anglo-Saxon era, then, churchmen began to undermine slavery as an institution, but only indirectly, by limiting the slave trade. One visible aspect of slavery, sale in the public market, was forbidden, but other aspects, such as social hierarchy and coerced labour, were not brought into question and could continue in another form, such as serfdom.

Slavery was a complex, many-sided institution that made the role of the church similarly complex. Almost all the evidence from the fifth to the eleventh centuries presents slavery as an unremarkable part of everyday life, in which the church and its officials were as deeply involved as all the other Christians who formed Anglo-Saxon society. Churchmen wrote laws that assumed the existence of slavery, compromised on teachings about marriage when slavery unexpectedly intruded, and used slavery to enforce their doctrines. They, like other Christians, owned slaves and occasionally freed them, whether for the good of their own souls or to show God's power, all the while knowing that to be a slave was to be pitied. Yet at the same time, slavery was a common way of thinking about the relationship of God to humanity and, in this context, was seen as desirable. To be the devil's (or sin's) slave meant etemal death, to be another man's slave was to suffer bitter misfortune, but to be God's slave was glorious. The contradictions deriving from the conflicting pictures of the miserable lot of the slave on earth on the one hand and the sublimity of humanity's relationship to God on the other was never explicitly confronted. Instead, slavery in England quietly faded away. Its problems were not resolved, merely set aside.

${ }^{81}$ Dorothy Whitelock, M. Brett, and C.N.L. Brook, eds., Councils and Synods volume I part 2 (Oxford: Clarendon Press, 1964), 418. 